\title{
Financial Performance and Corporate Governance in Microfinance: Evidence from Vietnam
}

\author{
Thi Dieu Thu Nguyen \\ University of Transport Technology, Vietnam \\ Van Dang Pham \\ Ha Noi University of Business and Technology, Vietnam \\ Thi Hue Dang, Thi Thai An Nguyen \\ University of Transport Technology, Vietnam \\ Manh Dung Tran \\ National Economic University, Vietnam \\ Thi Thu Huyen $\mathrm{Vu}$ \\ Thuongmai University, Vietnam
}

\begin{abstract}
Good corporate governance is considered a building block of success for microfinance institutions (MFIs) as it is presumed to help them in achieving their social and financial goals. This study analyzes the corporate governance and financial performance relationship for MFIs in Vietnam. We construct a corporate governance index based on seven measures pertaining to board size and composition, CEO characteristics, and ownership type. We then estimate the two-way relationship between this index and each of five different financial performance indicators. To address the likely simultaneity between corporate governance and financial performance, we adopt a two-stage least squares estimation approach with instrumental variables. The results confirm the endogenous nature of corporate governance and financial performance. We conclude that profitability and sustainability of MFIs improve with good governance practices and conversely that more profitable and sustainable MFIs have better governance systems.
\end{abstract}

Keywords: Corporate governance, financial performance, microfinance.

DOI: $10.7176 / \mathrm{EJBM} / 12-3-12$

Publication date: January $31^{\text {st }} 2020$

\section{Introduction}

Poverty is a major problem in many developing countries including emerging countries and many efforts are being made by governments and institutional parties for overcoming it. For many decades, subsidized credit was provided to the poor of the society as 'cost of credit' was considered a major problem faced by many poor people. However, then came the realization that the major concern of the poor was not the 'cost of credit' but 'access to credit' that non-access to credit and other financial services is a major obstacle to prosperity of poor people in developing countries (Hermes \& Lensink, 2007), and Vietnam is not an exceptional case.

Microfinance serves as a lifesaving instrument as it provides financial and social services to the underprivileged and excluded members of society, who have no access to traditional financial services offered by conventional financial institutions. The concept of microfinance emerged formally in the 1970 when Yunus started his micro-lending program in Bangladesh in response to increased poverty levels (Daher \& Saout, 2013). Since microfinance institutions (MFIs), especially in Asia, were developed in response to prevailing poverty conditions, they have played a major role in economic and financial development. As most MFIs in Asia and Vietnam offer services exclusively to women, they bring about female empowerment and gender equality. Other benefits of microfinance are education for children, improved health and standard of living of people, and increased employment levels in regions where a majority of the population lives below the poverty line. Therefore, it is very important to investigate and bring advancement in microfinance.

Good corporate governance (CG) is seen as a basic building block of success for MFIs as it helps them in achieving their social and financial goals. It is defined as the mechanism for setting goals and objectives of company and the means of achieving those goals and objectives.

In the context of microfinance, the term 'governance' was first used by CGAP in 1997 as a system of checks and balances in an institution where a board acts as the supervisory body. The field of corporate government arises in a context where agency conflicts are present.

Agency theory states that the managers are the controllers of the firm while shareholders are the owners, and a conflict is present between their interests. Corporate government provides a solution to the problems arising from 
agency conflicts and is defined as the mechanism which forces managers to act in the best interest of shareholders. Failure to implement practices of good governance can lead to the downfall of MFIs or undermine their effectiveness due to poor decisions, reduced access to funds in the form of capital or donations, and compromised goodwill and trust.

However, measurement of corporate government and detailed analysis of the nexus between corporate government and financial performance (FP) remains an underdeveloped area particularly with respect to Vietnam MFIs. The general literature on corporate government highlights the importance of studying the direction of causality between corporate government and performance. This is still an under researched area in the microfinance literature.

The present study responds to the need for better understanding of the governance mechanism in MFIs by studying the relationship between corporate government and financial performance in the Vietnamese context. As corporate government plays a critical role in improving the overall financial performance of MFIs, the comprehensive measurement of corporate government is of great importance. An important contribution of this study is that we employ various characteristics of corporate government, for example with respect to leadership and ownership structure, to construct a corporate governance index (CGI) specifically for MFIs in Vietnam economies. We take a different approach the present study builds a corporate governance framework tailored to the Vietnamese context.

This research also responds to the need for better understanding of the causal relationship between corporate government and financial performance of MFIs, by studying first whether good governance in MFIs leads to improved financial performance, and then whether more financially sustainable MFIs are also better in their governance structures

\section{Theoretical framework and hypothesis}

Corporate governance is defined as the mechanism for setting the goals and objectives of company and the means for achieving those goals and objectives. It involves the relationships among a company's top management, board of directors, shareholders, and other stakeholders such as employees and customers (OECD principles of corporate governance, 2004)

The field of corporate governance analysis arose from a recognition of agency conflicts present within the firm. Agency theory states that the managers are the controllers of a firm while shareholders are the owners and there is a conflict between their interests. Corporate government provides a solution to the problems arising from agency conflicts. Forms of the solution can involve binding managers in contracts, monitoring them, or providing them with incentives (Denis, 2001).

Different views are present in the literature on the nature of the corporate governance and financial performance relationship. Some studies assume corporate governance to be an exogenous variable that influence firm performance while an alternative view suggests that corporate governance itself is influenced by prior firm performance hence pointing to its endogenous nature. Many studies in the broad corporate governance literature have treated corporate governance as exogenous to firm performance (Chen et al., 2007; Fernandez \& Gomez, 2002).

Many studies have provided a rationale for two-way or reverse-causality between corporate governance and FP in studying corporate governance variables endogenously. Some have highlighted the importance of studying the direction of causality.

To conclude, the literature points to the possibility that corporate governance and financial performance may be jointly determined, hence suggesting the presence of reverse or two-way causality in their relationship. This is still an under-researched area in the microfinance literature, and the present study tries to fill this gap by studying the two-way relationship between corporate governance and financial performance of Vietnam MFIs.

This research looks into the presence of two-way causality between corporate governance and financial performance for MFIs. First, it investigates how improving corporate governance can raise financial performance in MFIs. Then, it looks at whether higher financial performance leads to better governance structure. This paper however, takes a different approach from the literature in the sense that instead of following standard corporate governance measurement practices employed developed countries, we build a corporate governance framework based on leadership and ownership variables tailored to MFIs in the Vietnam context to create an index to proxy corporate governance quality.

Based on the foregoing discussion, we posit the following hypothesis: H1: Corporate governance impacts the financial performance of MFIs.

\section{Research methodology}

\subsection{Corporate governance index}

In the context of microfinance, the term 'governance' was first used by the Consultative Group to Assist the Poor in 1997 to refer to a system of checks and balances in an institution where a board acts as a major supervisory 
body. Campion et al. (2008, p. 73) defined corporate governance in MFI's as " the process by which stakeholders guide the MFI to define and protect the mission and the institutions assets".

Corporate governance practices in microfinance are differentiated from other sectors of the economy because of the dual mission of MFIs. Thus, corporate governance in microfinance can be divided into two dimensions: leadership structure and ownership structure. Leadership structure involves issues related to the board of directors and the top management team while ownership structure deals with different institutional setups in microfinance.

The board is the most important element of leadership and control because it is the board that has the final power and responsibility over firm decisions. The board acts on behalf of shareholders to serve as liaison with managers. Agency theory advocates separating management decisions from corporate control by differentiating the roles of CEO and chairman of the board. The board is thus empowered to guide managers in making strategic decisions and to monitor and supervise them in acting on those decisions (Jensen, 1993).

As the microfinance sector of Vietnam was developed specifically for the purpose of serving a social mission, unlike its counterpart in the United State of America and Europe, it is more effective to construct a corporate governance framework that reflects this distinctiveness.

For example, women clients are generally considered the best target market for MFIs, as microfinance focuses on the provision of financial services to small informal sector businesses that are mostly run by women as a form of self-employment. MFIs could thus benefit by female leadership as females know better the kinds of products females like and how to target them. This argument is also supported by resource dependence theory. Many of the MFIs are non-profit organizations which are considered weak in governance structure because of high agency problems and low involvement of boards in monitoring management.

Hence, instead of following the analytical practices adopted by MFIs in developed countries, the present study builds a corporate governance analytical framework related to leadership and ownership dimensions, focusing on MFIs in the Vietnamese context.

In conventional financial institutions, international directors are thought to be linked with superior business practices and improved financial performance. In the case of microfinance, local directors are considered more effective for performance as they have more knowledge about the local area and market trends. International directors are linked with higher financial costs in MFIs.

\section{CEO/chairman duality}

$\mathrm{CEO} /$ Chairman duality is defined as the presence and influence of the CEO on the board of a firm. According to agency theory, the roles of the CEO and board chair should be separated so as to distinguish management decisions from corporate control. CEO duality gives more power and freedom in decision making to the CEO hence bringing conflict between owners and management, and ultimately reducing firm performance.

\section{Female CEO}

Microfinance focuses on the provision of financial services to small informal sector businesses involving selfemployment.

\section{Ownership type}

Ownership type plays a very important role in the overall performance of MFIs because of their basic mission. Nonprofit organizations are generally considered more socially oriented while for-profit shareholder owned firms are considered more commercially oriented. In nonprofit organizations agency problems are higher because of their week governance structure and low board involvement in monitoring management since they do not represent investors. Due to this, CEO decision making power in nonprofit organization tends to be greater than in shareholder firms which leads to less financially sound decisions.

\subsection{Sample and data}

The microfinance sector in Vietnam was founded with the mission to offer financial services to the poor who were being excluded from conventional financial services. Microfinance has developed mainly in Asia where, given the vast population, most of the world's poor are concentrated. In 2018, about 72 percent of the poor in Vietnam lived in rural areas and ethnic minority areas. This population forms an immense client base for microfinance, which has not gone unnoticed. Therefore, we focus on the microfinance sector of Vietnam as it plays an important role in the financial and economic development of Vietnam in the integration of international and economic aspects.

\subsection{Financial performance}

This study employs accounting based measures to assess the performance of MFIs rather than market based measures because many of the MFIs are private financial institutions that lack market-based measures. Key measures used for assessing profitability are return on assets (ROA); return on equity (ROE); portfolio yield $(P Y)$; and operating expense ratio $(O E R)$. These indicators are in keeping with standard analytical practice. It is important to assess the performance of an MFI in terms of its self-sufficiency because day by day many MFIs are becoming commercialized and self-dependent instead of relying on subsidies and donations.

Firm risk is a firm-specific determinant that affects corporate governance practices and is taken as a control 
variable of this study. That firms facing greater risk must be better governed as they need strict monitoring systems. MFIs can be classified into three types based on their lending methodology: individual lenders; group lenders; and village banks.

The human development index (HDI) is used as a country control when studying the effects of corporate governance on financial performance. HDI is a UNDP indicator that assesses the development of countries based on people of the country and their capabilities. It covers three dimensions; standard of living; knowledge; and life expectancy. A higher value indicates higher productivity of the labor force of the country which is expected to increase the financial performance of firms.

The variables are defined as:

CGI $=$ Corporate Governance Index;

$\mathrm{ROA}=$ return on assets;

$\mathrm{ROE}=$ return on equity;

OSS = operational self-sufficiency;

$\mathrm{PY}=$ portfolio yield;

OER = operating expense ratio;

PAR30 = portfolio at risk 30 days;

HDI = Human Development Index;

\section{Results and discussion}

\subsection{Descriptive statistics}

Table 1 shows descriptive data of financial and controlled variables.

Table 1: Descriptive statistics for financial and control variables

\begin{tabular}{|c|c|c|c|c|c|}
\hline Items & Measurement & Min & Max & Std & Dev \\
\hline ROA & $\begin{array}{l}\text { net income after taxes and before donations/average } \\
\text { assets. }\end{array}$ & 265 & -0.050 & 0.025 & 0.035 \\
\hline ROE & $\begin{array}{l}\text { net income after taxes and before donations/average } \\
\text { equity. }\end{array}$ & 265 & -0.200 & 0.130 & 0.170 \\
\hline $\begin{array}{l}\text { Operational } \\
\text { selfsufficiency } \\
\text { (OSS) }\end{array}$ & $\begin{array}{l}\text { financial revenues/(financial expenses + loan loss } \\
\text { expenses }+ \text { operating expenses }) \text {. }\end{array}$ & 265 & 0.650 & 1.145 & 0.225 \\
\hline Portfolio yield (PY) & $\begin{array}{l}\text { [(Interest, Fees, and Commissions on Loan } \\
\text { Portfolio/Average Gross Loan Portfolio })- \text { Inflation } \\
\text { Rate }] /(1+\text { Inflation Rate }) \text {. }\end{array}$ & 265 & -0.045 & 0.165 & 0.100 \\
\hline $\begin{array}{l}\text { Operating Expense } \\
\text { Ratio (OER) }\end{array}$ & operating expenses/average gross loan portfolio. & 265 & 0.009 & 0.147 & 0.078 \\
\hline Age & years since establishment. & 265 & 1 & 10 & 8 \\
\hline Size & $\begin{array}{l}\text { log of assets. } \\
\text { (outstanding balance on loans in arrears over } 30\end{array}$ & 265 & 0 & 7.100 & 0.750 \\
\hline Risk (PAR30) & $\begin{array}{l}\text { days }+ \text { total refinanced or } \\
\text { loans)/outstanding gross portfolio. }\end{array}$ & 265 & 0 & 0.018 & 0.290 \\
\hline $\begin{array}{l}\text { Human } \\
\text { Development Index } \\
\text { (HDI) }\end{array}$ & $\begin{array}{l}\text { index of living standard, life expectancy and } \\
\text { education. }\end{array}$ & 265 & 0.400 & 0.550 & 0.085 \\
\hline
\end{tabular}

Note: Data are for 100 MFIs over a three-year period.

CGI is an ordinal variable, constructed using seven corporate governance variables related to leadership and ownership structure. Its values range from 0 to 7. Descriptive statistics are shown in Table 2. Our panel is structured in such a way that corporate governance variables are constant for a given MFI over the time period as governance structure of the firms is generally stable over time. However, considerable variation is shown across MFIs. Four MFIs attained the maximum score of seven meaning governance structures of high standard. 
Table 2: Descriptive Statistics for CGI

\begin{tabular}{cccc}
\hline CGI & Frequency & Percent & Cum. \\
\hline 1 & 1 & 0.5 & 0.5 \\
2 & 5 & 10.5 & 5.8 \\
3 & 18 & 18.0 & 18.4 \\
4 & 24 & 25.2 & 25.6 \\
5 & 23 & 28.0 & 53.2 \\
6 & 25 & 15.5 & 67.7 \\
7 & 4 & 2.3 & 100 \\
Total & $\mathbf{1 0 0}$ & $\mathbf{1 0 0}$ & \\
\hline
\end{tabular}

\subsection{Discussion}

All financial indicators (proxied by ROA, ROE, OSS, PY) except OER are positively and highly significantly correlated with each others, which confirms that these indicators are various dimensions of financial performance broadly. OER has a negative and highly significant correlation with all financial indicators except PY. The positive and highly significant association with PY indicates that MFIs having higher administrative and overhead costs earn higher yields on their portfolios.

None of the financial variables are significantly correlated with CGI. This shows that CG as captured by our measure is not related with financial proformance. This may be because MFIs, especially in emerging countries like Vietnam and in Asia, are more socially oriented with goals like poverty reduction and female empowerment. These results are in line with of Strom et al. (2014) who found negative and insignificant correlation of ROA, ROE, and OSS with corporate governance variables.

The positive and highly significant correlation of age with ROE, and negative and significant correlation of age with OER show that MFIs earn higher profits and bear lower costs as they get older. Age has insignificant correlation with CGI. Size which is measured by log of assets of firms has positive and highly significant correlation with CGI which shows that larger MFIs are better governed.

\section{Conclusion}

This research fills the gap and extends the literature on governance mechanisms in MFIs by investigating the relationship between corporate governance and financial performance in Vietnamese context as a case study and an illustration of emerging countries. The dataset was collected and involves 100 MFIs from Vietnam of three years from 2016 to 2018. We construct a firm-level index of corporate governance based on aspects of leadership and ownership structure that is tailored to the functioning of MFIs in Vietnam. Specifically, the index incorporates seven elements representing board size; board diversity with respect to gender, financial expertise, and local residency; $\mathrm{CEO} /$ chairman duality; female $\mathrm{CEO}$; and shareholding ownership type. We then examine the relationship between the governance index and each of five measures of financial performance. In view of the simultaneity that is likely to exist between corporate governance and financial performance, we adopt a two-stage least squares estimation approach with instrumental variables.

For purposes of comparison, single equation estimation was undertaken for each of the five financial measures regressed on the governance index and the governance index regressed on each of the five financial measures, along with control variables. In no case was any statistically significant relationship found. Under the simultaneous equation framework, by contrast, statistically significant relationships emerge in both directions for most of the financial performance measures. Thus corporate governance is found to influence a variety of financial performance measures and in turn the financial performance measures are found to affect corporate governance. A statistical test for endogeneity further confirms the appropriateness of the simultaneous equations approach.

A number of exogenous variables are also found to have an effect on the variables of interest. MFIs that provide only individual-based lending are found to perform better financially than those that include group loans in their portfolios. Those with riskier portfolios as measured by loans that are 30 days past due are found to perform less well. By contrast, MFIs that provide individual-based lending only are found to have lower corporate governance scores. The legal status of bank for an MFI is found to be associated with better governance than other legal forms (rural bank, non-bank financial institution, non-government organization, or credit union).

While this study has focused on financial performance as an outcome, most MFIs in Vietnam are not established with financial success as their main goals. Rather, social goals, such as poverty alleviation and female 
empowerment, are generally foremost. In view of this, a topic for future research would involve examining the relationship between corporate governance and the achievement of social goals and more broadly the three-way relationship that also encompasses financial performance.

\section{References}

Campion, A., Linder, C., \& Knotts, K. (2008). Putting the 'social' into performance management. Institute of Development Studies at the University of Sussex, Brighton.

Chen, C.W., Lin, J. B., \& Yi, B. (2007). CEO duality and firm performance: An endogenous issue. Corporate Ownership and Control, 6(1), 58-65.

Chowdury. P.R. (2005). Group lending: sequential financing, lender monitoring and joint liability. Journal of Development Economics, 77(2), 415-439.

Daher, L., \& Saout, E. L. (2013). Microfinance and financial performance. Strategic Change, 22(1-2), 15-22.

Denis, D. K. (2001). Twenty-five years of corporate governance research. Accounting Review, 10(3), $191-212$.

Jensen, M. C. (1993). The modern industrial revolution, exit, and the failure of internal control systems. The Journal of Finance, 48(3), 831-880.

Ghatak, M. (2000). Screening by the company you keep: joint liability lending and the peer selection effect. Economic Journal, 110(465), 601-631.

Hermes, N., \& Lensink, R. (2007). The Empirics of microfinance: What do we know? The Economic Journal, 117(517), 1-10.

Karlan, D. (2007). Social connections and group banking. Economic Journal, 117, 52-84.

OECD (2004). Principles of corporate governance publications service, policy brief.

Sharma, M. \& Zeller, M. (1997). Repayment performance in group-based credit programs in Bangladesh: an empirical analysis. World Development, 25(10), 1731-1742.

Streeten, P. (1994). Human development: Means and ends. The American Economic Review, 84(2), $232-237$.

Weiss, J. \& Montgomery, J. (2004). Great expectations: microfinance and poverty reduction in Asia and Latin America, ADB Institute discussion paper No. 14, The Asian Development Bank Institute.

World Bank (2019). The State of the Poor: Where Are the Poor... What is the current profile of the World's poor?".

Zeller, M. (1998). Determinants of repayment performance in credit groups: the role of program design, intragroup risk pooling and social cohesion. Economic Development and Cultural Change, 46(1), 599-620. 